\title{
COMPETENCY BASED PAY SYSTEM DESIGN AT KURSUS INDONESIA
}

\author{
Rahma Dinda Dwi Putri ${ }^{1 *}$ and Aurik Gustomo \\ ${ }^{1,2}$ Institut Teknologi Bandung, Bandung, Indonesia
}

\begin{abstract}
In today globalization era, competition among business is getting tighter, and it is not only about attracting customers but also attracting and retaining human capital. Kursus Indonesia have a difficulty in attract and retain their employee, and founded that their current compensation not yet satisfying their employees. This study aims to find the root cause of Kursus Indonesia's compensation problem, design a strategic compensation system and compare the new compensation proposed salary with benchmark salary. This study used qualitative research method and the data used are primary data (interview and observation) and secondary data (literature study). To process the data gained, this study used descriptive analysis with business situation analysis and current reality tree root cause analysis, job analysis and point method job evaluation. This study found that (1) The root cause of Kursus Indonesia's compensation problem is no alignment between the current compensation strategy with company's business strategy; (2) Design a Competency Based Pay system is a suitable approach to solve Kursus Indonesia's compensation problem; (3) This solution propose some improvent in Kursus Indonesia's employee salary by using Lead Pay Policy that pay above benchmark salary.

Keywords: Attract and Retain, Compensation, Competency Based Pay, Competition, Salary
\end{abstract}

\section{INTRODUCTION}

The era of globalization today becomes a reality that must be faced by every country, not least Indonesia. This era affects the increasingly tight competition among business and the bluring of boundaries to enter industry. For that each business should have strong competitive advantage to gain strategic competitiveness. Human has a very important role to face competition today, as Robert J. Eaton, once said, the only way we can beat the competition is with people (Moeljono, 2003:68). The major challanges today is to meet the increasing demand of qualified and unique human resources. Company have to be able to attract and retain its qualified employees, and compensation has a big influence to that.

Kursus Indonesia as a company engaged in bimbel or tutoring industry, was not strongly competitive yet compared to it's competitors. Table 1 shows that Kursus Indonesia does not appear on the list of five Top Brand Bimbel for teen in Indonesia from year 2015 until 2017.

\footnotetext{
* Corresponding author. Email address: $\underline{\text { rahma.dinda@sbm-itb.ac.id }}$
} 
Table 1 Top Brand Bimbel for Teen Year 2015-2017

\begin{tabular}{|c|c|c|c|c|c|c|c|c|}
\hline \multicolumn{3}{|c|}{2015} & \multicolumn{3}{|c|}{2016} & \multicolumn{3}{|c|}{2017} \\
\hline Brand & TBI & TOP & Brand & TBI & TOP & Brand & TBI & TOP \\
\hline $\begin{array}{l}\text { Ganesha } \\
\text { Operation }\end{array}$ & $31.2 \%$ & TOP & $\begin{array}{l}\text { Ganesha } \\
\text { Operation }\end{array}$ & $29.3 \%$ & TOP & $\begin{array}{l}\text { Ganesha } \\
\text { Operation }\end{array}$ & $32.0 \%$ & TOP \\
\hline Primagama & $14.1 \%$ & TOP & Primagama & $24.3 \%$ & TOP & Primagama & $17.2 \%$ & TOP \\
\hline Kumon & $11.7 \%$ & TOP & Nurul Fikri & $10.5 \%$ & TOP & Nurul Fikri & $12.9 \%$ & TOP \\
\hline Nurul Fikri & $6.8 \%$ & & Kumon & $6.1 \%$ & & Kumon & $10.6 \%$ & \\
\hline Medica & $4.0 \%$ & & Medica & $5.0 \%$ & & SSC & $4.2 \%$ & \\
\hline
\end{tabular}

Source: www.topbrand-award.com

This competitiveness problem could caused by several factors within all management fields in the company. In terms of finance and marketing, the achievement of revenue target and students target has not been optimal yet, with the average target student and target revenue achievement was only about $70 \%$ in 2017. In terms of operation, Kursus Indonesia does not have a structured performance management system to help manage corporate performance. In other area, Kursus Indonesia also does not have strong technological and research and development resource that important in adapting tecnological and industry changes. In terms of human resources, Kursus Indonesia has not been able to attract and retain its employees optimally. Based on the company's internal data, in 2017 the new employee recruitment target achievement is not optimal. The average achievement of new employee target from January to September 2017 is only about $54.44 \%$. This problem indicates that company have difficulty in attracting new employee to join Kursus Indonesia.

In addition to being less than optimal in attracting potential employees, Kursus Indonesia also has a severe disadvantage in terms of retaining their employees. for the period of 2016, Kursus Indonesia employee turnover was very high, rated $70.7 \%$, and in the period of 2017 the rate decreasing but still very high, rated $48.7 \%$. Kursus Indonesia has not yet capabale in making their employees stay and keep engage with the company.

Based on an employee satisfaction survey conducted by internal Kursus Indonesia, eight factors was measured to know the employees satisfaction and also measured the level of those factors importance in affecting employee productivity and performance improvement. An Importance Performance Matrix was made to analyzed the survey result as seen in Figure 1, employee preferences of the factors presented as Importance in the $\mathrm{Y}$ axis and employee satisfaction of the factors presented as Performance in the $\mathrm{X}$ axis. 


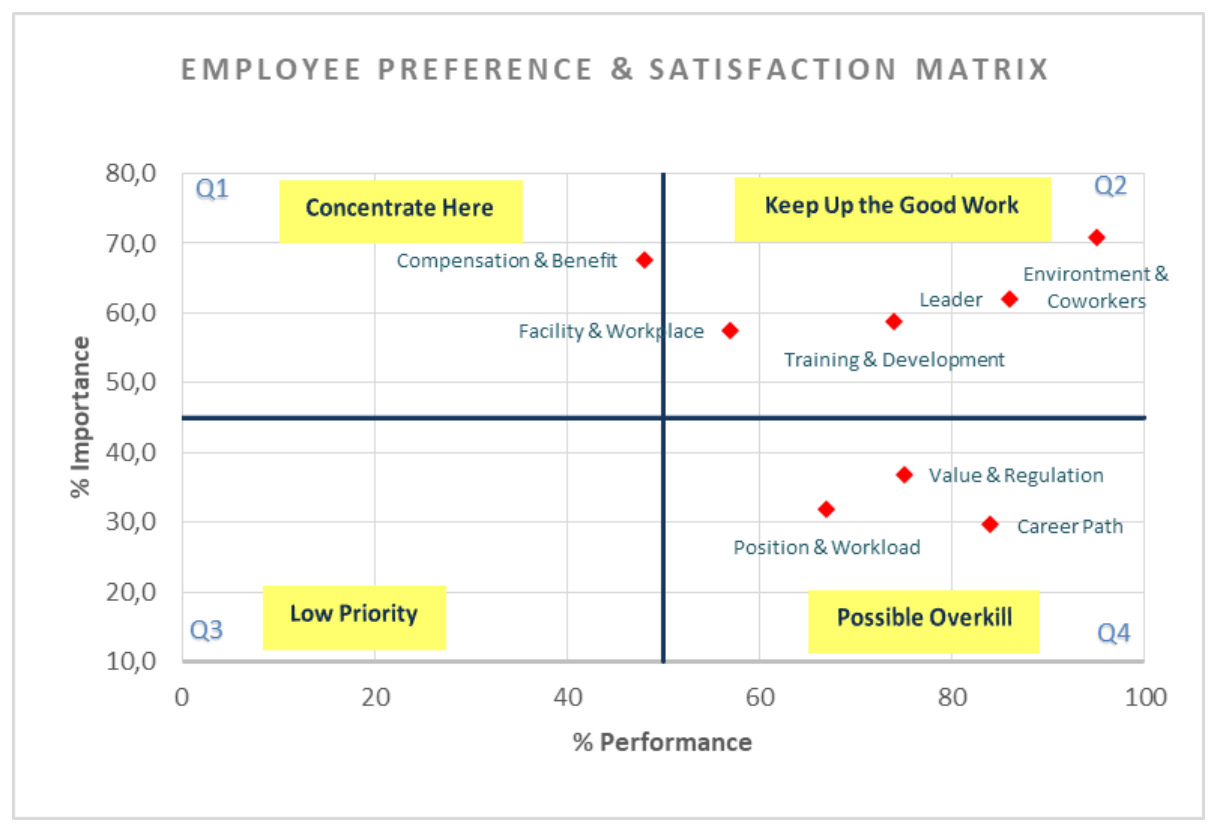

Figure 1 Importance Performance Matrix

(Source: Kursus Indonesia Indonesia (Processed))

One factor that comes in quadrant 1 is Compensation and Benefit, where it has a high importance but the result of performance or employee satisfaction against it is low, indicates that compensation and benefit factor needs to be concentrated for deeper improvement. Compensation and benefit factors obtained the lowest satisfaction score results, with above $50 \%$ dissatisfaction. This condition could make employees' motivation weakened then lead them to produce performance that is less satisfactory. So this study aims to find the root cause of Kursus Indonesia's current compensation problem, design a strategic compensation system and compare the new compensation system's proposed worth salary with benchmark salary.

\section{LITERATURE STUDY}

This study using two conceptual framework from macro level view and messo level view. The macro level framework describes the variables and factors affecting the issue, and related concepts to solve the issue in broad view as illustrated in Figure 2. In order to face the tight competition known from competitor analysis and five forces analysis, Kursus Indonesia should have a sustainable competitive advantage. As explained in the book Strategic Management: Competitiveness and Globalisation, a sustainable competitive advantage is source for a firm to achieve strategic competitiveness and earn above-average returns (Hitt, Ireland, \& Hoskisson, 2002). With internal analysis and SWOT analysis could be known the current Kursus Indonesia competitive advantage condition. 


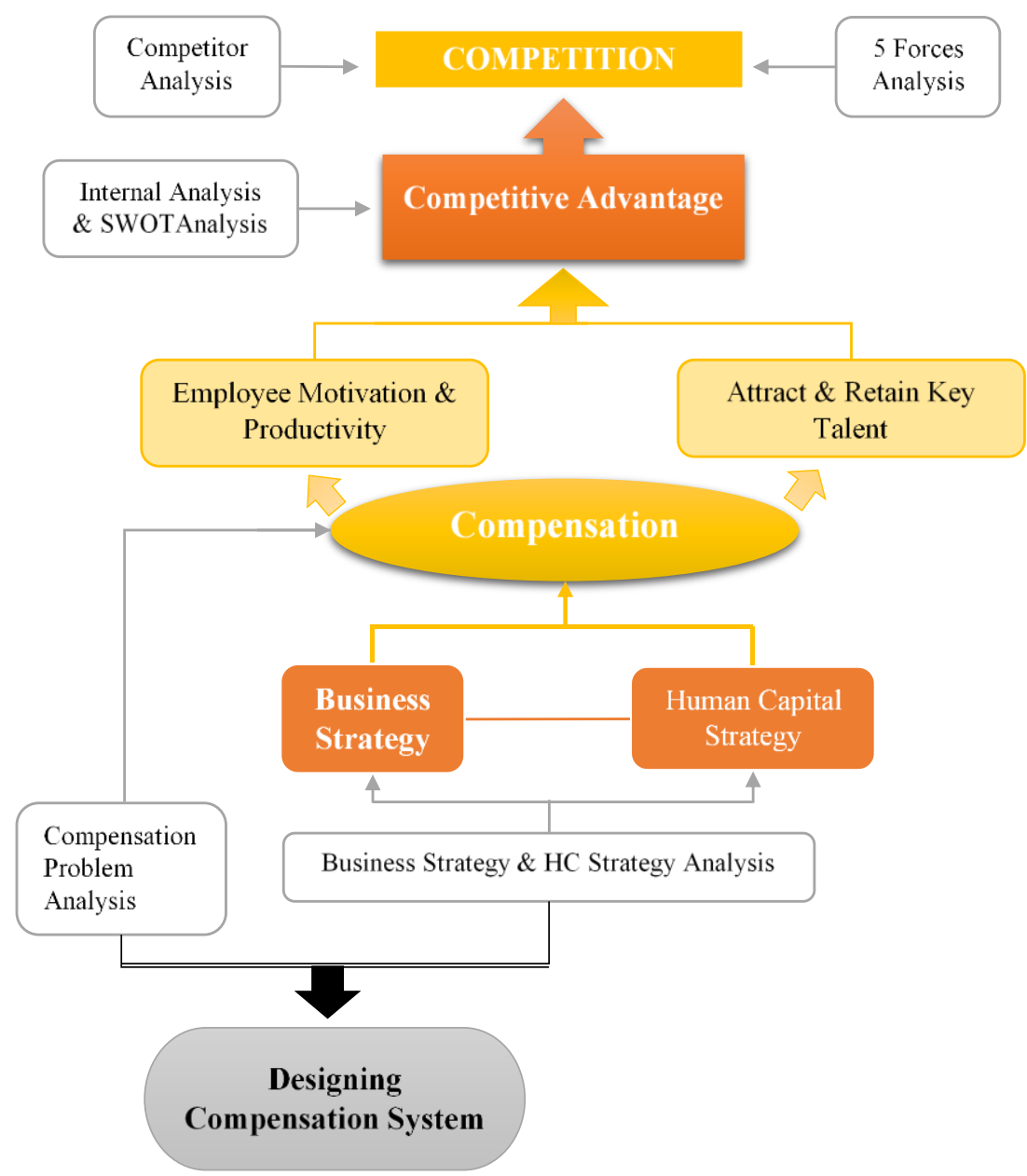

Figure 2 Conceptual Framework (Macro Level)

In terms of human resources (HR), one emphasized way to gain and sustain competitive advantage is to attract and retain key employee. Because attract and retain key talent is one of human resource matter in achive competitive advantage. But, Alex Denni (2011) explained in his disertation, that human resource management system which is developed in industrial era, has been transformed towards a human capital approach in the era of global and information recently. Humans who used to be called as resources before, are defined as the most valuable assets for the company nowadays. Human capital is an appropriate approach in value-creating strategy, as Kearns (2006) revealed that human capital management focuses on adding and creating value for human development (Baron, 2007).

Compensation is one of important factor in creating value of attract and retain key talent and boost employee motivation and productivity. Compensation management motivates the employees and improving organizational effectiveness (Naukrihub, 2015). Singh (2007) also stated that compensation helps to retain competent employees in the organization. With analyzing the current Kursus Indonesia's compensation system problem could be known the weakness and area of improvement to the compensation system. Therefore, the determination of compensation system used for improvement must be considered comprehensively in order to strengthen company's competitive advantage. 
A currently popular theory found in almost every book and consultant's report tells manager to tailor they pay systems to align with the organization's business strategy (Milkovich, Newman \& Gerhart, 2014). A compensation strategy that supports the business strategy implies alignment between compensation and overall human capital strategy. So the analysis of current Kursus Indonesia's business strategy and human capital strategy is needed to a make an alignment between those strategies and compensation strategy. Milkovich, Newman and Gerhat (2014) also said that the strategic perspective focuses on those compensation choices help the organization gain a sustain competitive advantage.

This study will solve the Kursus Indonesia's current compensation problem by designing a new compensation system in terms of base salary, not to the overall total compensation. Meso level conceptual framework shows the corresponding variables, steps, and their interrelationships in designing compensation system as seen in Figure 3.

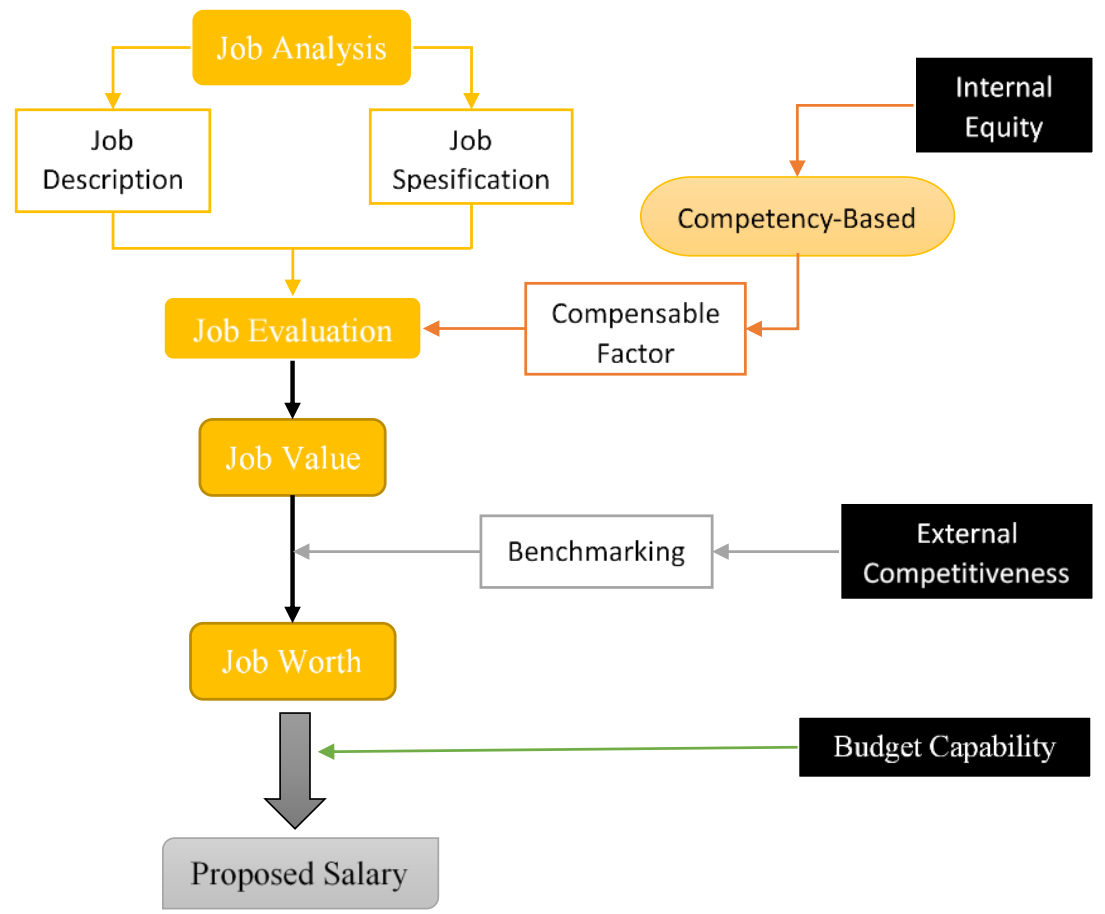

Figure 3 Conceptual Framework (Meso Level)

\section{RESEARCH METHODOLOGY}

This study used qualitative research method that emphasize the valueladen nature of inquiry and seek answers of questions that stress how social experience is created and given meaning. In the handbook of qualitative research Denzin and Lincoln describe qualitative research as involving an interpretive naturalistic approach to the world. This means that qualitative research study things in their natural settings, attempting to make sense of or interpret phenomena in terms of the meanings people bring to them (2005: 3).

Data collected in this study are primary data and secondary data. The primary data used in this research were obtained by discussion with company's executives, interview employees, and direct field observation. The primary data were about employees' view of current compensation system, job description 
and job specification, current company and employees' performance, current compensation system, and other internal information. In this study, the secondary data was obtained by gathering some data from other source outside the company. Those data are benchmark salary, industry top brand data, industry situation, competitors' data and other complementary data.

To process the data gained, this study used descriptive analysis with business situation analysis that consists of environmental scanning, current business strategy and human capital strategy analysis, current compensation problem analysis and leads to the current reality tree root cause analysis. From the root cause founded, the solution is to make a strategic compensation system and it could be done by doing job analysis and point method job evaluation. Job analysis consisted by job description analysis and job specification analysis. The point method job evaluation evaluates jobs by comparing compensable factors. According to Martocchio (2013), Job evaluation commitees follow seven steps to complete the point method:

1. Select Benchmark Jobs

2. Choose Compensable Factors

3. Define Factor Degrees

4. Determine the Weight of Each Factor

5. Determine Point Values for Each Compensable Factor

6. Verify Factor Degrees and Point Values

7. Evaluate All Jobs

\section{RESULTS}

\subsection{Environmental Scanning}

To view Kursus Indonesia's broader business conditions of the current situation of industry competition and their current competitive advantage, the environmental scanning with internal analysis and external analysis was conducted. This study used the Porter's Five Forces analysis and Competitor Analysis in the external analysis to see the competition faced in tutoring industry. 


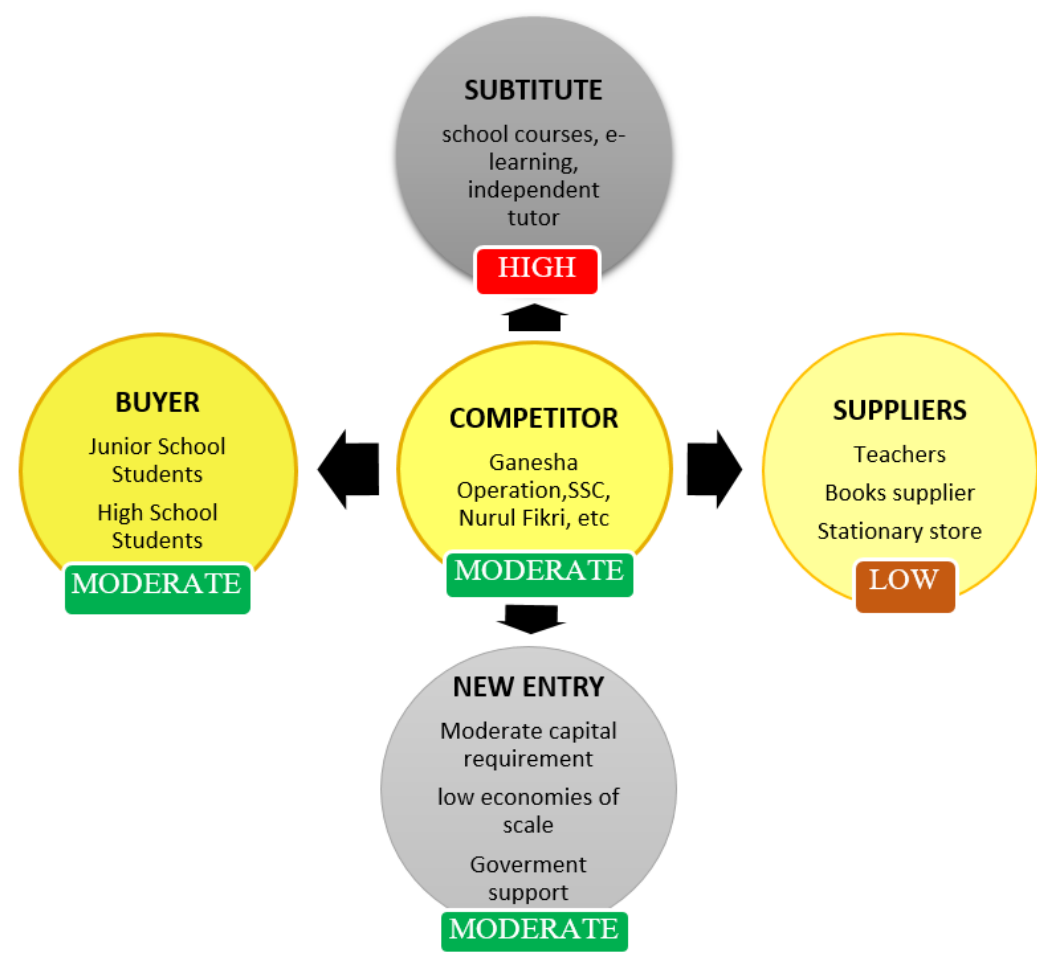

Figure 4 Five Forces Analysis Summary

Figure 4 is a summary of the five forces analysis conducted that shows the tutoring industry attractiveness and competition. In general, the stronger competitive forces are, the lower the profit potential for an industry. Based on above porter 5 forces analysis, tutoring industry is moderately competitive or attractive.

This study did a competitor analysis to Ganesha Operation, Sony Sugema College, and Nurul Fikri because of the similarity of the product, facilities, and quality with Kursus Indonesia, they also has a good brand position in the market. This study analyzed several strengths and weaknesses of those competitors.

The internal analysis process considers the firm's resources, capabilities, and core competencies as the foundation of competitive advantage. The analysis of Kursus Indonesia's resources, capabilities and core competencies was obtain from the research conducted by Zulkifli Said (2017) resulted that Kursus Indonesia does not have a sustainable competitive advantage. There is only one temporary competitive advantage, that was human resources' trust.

The data obtained from external and internal analysis are summarized in SWOT analysis. According to Jogiyanto (2005: 46), SWOT is used to assess the strengths and weaknesses of the company's resources and external opportunities and the challenges it faces. The SWOT analysis is shown in Table 2. 
Table 2 SWOT Analysis of Kursus Indonesia

\begin{tabular}{|c|c|}
\hline Strengths & Weaknesses \\
\hline Homy and small class & Unstable management system \\
\hline $\begin{array}{l}\text { High qualified teacher from reputable } \\
\text { university }\end{array}$ & High employee turnover rate \\
\hline Talents mapping \& finger reading & $\begin{array}{l}\text { Employees unsatisfaction of the } \\
\text { compensation }\end{array}$ \\
\hline $\begin{array}{l}\text { Student's graduation rate always above } \\
80 \%\end{array}$ & $\begin{array}{l}\text { Weak in data processing and data storage } \\
\text { management }\end{array}$ \\
\hline $\begin{array}{l}\text { Majority employees are young people in a } \\
\text { productive age }\end{array}$ & Lack of performance management system \\
\hline Academic and psychological approach & Difficulty in recruiting qualified employees \\
\hline & Lack of strategic planning \\
\hline & Lack of training program \\
\hline & Lack of employee work facilities \\
\hline & Unclear and unfair some company rules \\
\hline Opportunities & Threats \\
\hline Government regulation about UN & The products are easy to imitate \\
\hline Incresing people's income per year & Government policy of school hours addition \\
\hline $\begin{array}{l}\text { Increasing public awareness about the } \\
\text { importance of education }\end{array}$ & Existence of some free online tutoring \\
\hline $\begin{array}{l}\text { High market share opportunity for } \\
\text { education industry }\end{array}$ & High threats of subtitute products \\
\hline Globalization and free market & $\begin{array}{l}\text { Competitor's fast adaptation to } \\
\text { technological change }\end{array}$ \\
\hline
\end{tabular}

\subsection{Current Business Strategy and Human Capital Strategy}

As described in the conceptual framework, to obtain the right compensation strategy in a company, it is necessary to link or adjust the compensation strategy to the company's business strategy. According to Hitt, Ireland, \& Hoskisson (2002), in the book Strategic Management: Competitiveness and Globalisation,

Business-level strategies are concerned with a firm's industry position relative to those of competitors. Firm choose from among four generic businesslevel strategies to establish and exploit a competitive advantage within a particular competitive scope: Cost Leadership, Differentiation, Focused Cost Leadership and Focused Differentiation.

Business strategy promoted by Kursus Indonesia is Focus Differentiation Strategy. Because Kursus Indonesia is different from other tutoring institution, they positioned their company as an education consultant. But Kursus Indonesia segment is more focus on Highschool students, unlike other competitors that mostly cover a wider segment. The product offered by Kursus Indonesia is also distinguished with its competitors.

Michael E. Porter (1998) described some example of value creating activities associated with the differentiation strategy, in terms of human resurces management, compensation programs intended to encourage worker creativity and productivity. Indeed, Kursus Indonesia does not have a certain human capital strategy for their company. Kursus Indonesia might unaware or 
underestimate the importance of their human capital in order to achive company strategic competitiveness.

\subsection{Current Compensation Problem}

In the practice, employee dissatisfaction of Kursus Indonesia's current compensation happened because of several problems in the current compensation system. Based on the interview with three Kursus Indonesia's employees from different job and levels of position, there are some problems exists in the current Kursus Indonesia's compensation system:

1. Not all salaries match the regional minimum wage. And some are only equivalent to the regional minimum wage. (Compliance problem)

2. The majority of employees feel the salary is not fair. They said, there are some employees with different tenure but the salary remains the same. There are also jobs with the same tasks and workload but the salary is different. There is no basic clarity in the determination of salary at each position in the career path. Then the workload is not worth the salary earned because they work with much times and energy sacrified, but gained an unworth payment. (Fairness Problem)

3. The majority of employees also feel that the salary earned has not been able to motivate employees to give their best performance. Besides being a modest salary as well as the lack of bonus and reward system. (Efficiency Problem)

4. There is no clarity of overtime pay and payment. Payment for overtime session and wage for official traveling tend to be more often not paid (Compliance Problem)

Futher more, above problems shows that Kursus Indonesia current compensation system can't fulfill the objectives of pay model defined by Milkovich, Newman and Gerhart (2011) there are efficiency, fairness, and compliance with laws and regulations.

From the slight overview of the current Kursus Indonesia's compensation system that present some of the forms and amount of salary for some positions, founded some strange and uncertainty in the base salary determination. The same job positions from various directorate at the same level was assessed with different salary payments. In addition, there are two employees with different working periods of about one month, but oddly the base salary of employees with a shorter working period is even greater than employees with longer tenure. There are also three OJT staff with different working period, two of them have the same working period, but gain the different salary amount. Those problem shows that the current Kursus Indonesia compensation system does not have a clear bases for pay.

\subsection{Root Cause Analysis}

This research use the Current Reality Tree (CRT) as the tool for finding the root cause of current Kursus Indonesia's busines issue. The Current Reality Tree (CRT) is a logic tree designed specifically to find hidden system-level problems in complex situations (Dettmer, 2007). Steve Tendon (2012) explained that CRT relate the Undesirable Effect (UDE)s via a logical chain of cause and effect to Root Causes (RC). Figure 5 shows the root cause analysis of Kursus Indonesia's business issue. 


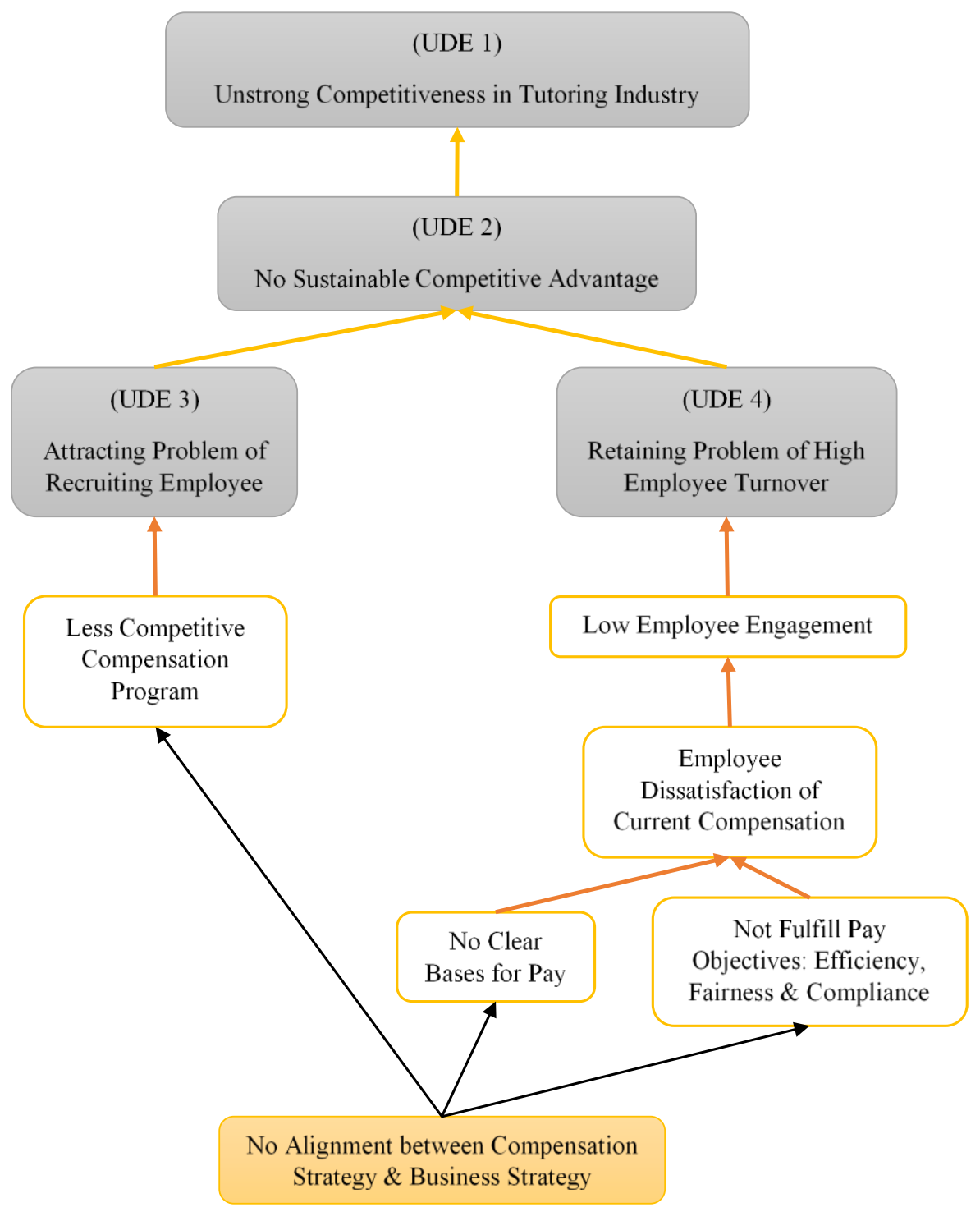

Figure 5 Root Cause Analysis

\section{DISCUSSION}

\subsection{Alternative Business Solution}

Problems with the current Kursus Indonesia's compensation system need to be addressed immediately by developing a new strategic compensation system that should aligned with company's business strategy. The compensation system itself by Berger \& Berger (2000) is grouped into four major components, namely Base Pay (salary), Benefit (benefits), Short Term Incentive and Long Term Incentive. In this study, the base salary compensation system emphasized because the base salary is the main component of Kursus Indonesia's compensation system and other forms of pay has not really implemented yet in Kursus Indonesia and not have any crucial problem.

\section{Bases for Pay}

Kursus Indonesia's current compensation system does not have a clear bases for pay, then, before develop a new system, it is necessary to determine which bases for pay that suitable and needed to solve the current compensation problem. There are several bases for pay proposed by Martocchio (2013), 
namely Traditional Bases for Pay, Incentive Pay, and Person-Focused Pay. Person-Focused Pay is the the bases for pay that most suitable to solve the current compensation problem. Advocates of person-focused pay programs offer two key reasons that firms seeking competitive advantage should adopt this form of compensation: technological innovation and increased global competition (Martocchio, 2013).

According to Martocchio (2013), Person-focused pay divided into competency-based, pay-for-knowledge, and skill-based pay. Competency Based Pay could fulfill the Kursus Indonesia's need for a pay structure that supports business strategy because it is suitable with service industry to improve employee motivation and play a central role for sustainable competitive advantage. As Ulrich and Smallwood (2004) explained that today, the integration of human resources management policies and systems with the explicit objective of creating fit and alignment between individual competencies and organizational capabilities, plays a central role for sustainable competitive advantage.

\section{Pay Structures}

The pay structure used in this research is Job Based Structure, that relate the salary with each job value. This pay structure could hep sustain company's competitive advantage and drives the ideal behaviors to each individual in their job. As Milkovich, Newman, and Gerhart (2011) explained that job based structures is one of design pay structures that will influence employee behavior and help organization sustain its competitive advantage.

\section{Job Evaluation Method}

In building an internally consistent compensation system, job evaluation is needed to be done. According to Milkovich, Newman \& Gerhart (2014), there are three types of job evaluation methods commonly used by company; Ranking Method, Classification Method, and Point Method. Before start designing a new system, it is necessary to determine what type of job evaluation to use. After discussion with Kursus Indonesia's General Manager Human Capital (GM HC), determined that Point Method job evaluation is a proper job evaluation method. As mentioned in Milkovich, Newman \& Gerhart (2014), the advantage of point method among other methods are; compensable factors call out basis for comparison, then compensable factors communicate what is valued.

\subsection{Analysis of Business Solution Proposed Competency Based Pay System}

From several approaches and methods of compensation system, determined that the Competency Based Pay system is the pay structure that best suits the business strategy, drives employee behavior and could help attract and retain the qualified talents. To design the competency based compensation system, stage that need to be done are Job Analysis and Job Evaluation.

\section{Job Analysis}

At this stage job analysis was done by collecting information about each position's job description and job specification. The job analysis was done for the benchmark jobs by interviewing human capital executive and some position's holders about the jobs's description and specification. The content of job description are task, performance indicator, authorities and work 
relationship. In the job specification, the competencies determined adjusted to the level of competency that inherent with each position.

\section{Job Evaluation}

The point method evaluates jobs by comparing compensable factors. According to Martocchio (2013), Job evaluation commitees follow seven steps to complete the point method.

\section{Step 1: Select Benchmark Jobs}

The salary datas was compared from three trusted Indonesia's Job Sites, which are Jobstreet.co.id, Job-like.com, and Qerja.com. Those sites are included in the 20 most trusted and best job sites in Indonesia that can be used as a reference based on research done by maxmanroe.com (2017). The companies choosed as benchmark are Ganesha Operation, Sony Sugema College and Nurul Fikri. After comparing various data of competitors salary, ten jobs chosen to be used as the benchmark jobs. There are General Manager, Senior Manager, Branch Manager, Supervisor, Educator, Academic Staff, Administration Staff, Customer Service, Freelance Tutor, and Operational. Those jobs chosen because those jobs common accross some different employers, and represent the entire range of jobs.

\section{Step 2: Choose Compensable Factors}

There are five competencies used as compensable factors, which are Core Comptency, Managerial Competency, Functional Competency, Technical Competency, and Working Condition. Most of those factors was refferred by Spencer and Spencer Competency Dictionary.

Factors defined and leveled based on Spencer and Spencer are $\mathrm{ACH} A$, ACH C, CSO, FLX, AT and DEV for Core Competency, OA, IMP, INT, DIR, TL for Managerial Competency and INFO, SCF, EXP, TW, CO for Functional competency. Working Condition and Technical Competency factors was arranged by discussion with Kursus Indonesia's GM HC, the subfactors and the levels determined based on job- and business-related. The subfactors for Technical Competency are Education and Experience. The Working Condition are consist of Comfort Level and Risk Accident.

\section{Step 3: Define Factor Degrees}

The determination of level of every competency for each bencmark jobs was done by focus discussion with Human Capital General Manager (GM HC) and some position's holder.

\section{Step 4: Determine the Weight of each Factor}

In this study, the compensable factors weighted by using Expert Choice software. Expert choice software is a multi-objective decision support tool based on the Analytic Hierarchy Process (AHP). In this step, GM HC is the person who has the authority in making the desicion of factor's importance comparation and the result shows in Table 3. 
Table 3 Compensable Factors and Subfactors Weight

\begin{tabular}{|c|c|c|c|c|}
\hline FACTOR & $\begin{array}{l}\text { Factor } \\
\text { Weight }\end{array}$ & $\begin{array}{c}\text { Sub } \\
\text { Factor }\end{array}$ & $\begin{array}{c}\text { Sub } \\
\text { Factor } \\
\text { Weight }\end{array}$ & $\begin{array}{c}\text { Total } \\
\text { Weight }\end{array}$ \\
\hline \multirow{6}{*}{ Core Competency } & \multirow{6}{*}{$38,30 \%$} & $\mathrm{CSO}$ & $26,20 \%$ & $10,03 \%$ \\
\hline & & FLX & $9,30 \%$ & $3,56 \%$ \\
\hline & & $\mathrm{ACH} \mathrm{A}$ & $14,30 \%$ & $5,48 \%$ \\
\hline & & $\mathrm{ACH} \mathrm{C}$ & $15,50 \%$ & $5,94 \%$ \\
\hline & & $\mathrm{AT}$ & $14,70 \%$ & $5,63 \%$ \\
\hline & & DEV & $20,00 \%$ & $7,66 \%$ \\
\hline \multirow{5}{*}{$\begin{array}{l}\text { Managerial } \\
\text { Competency }\end{array}$} & \multirow{5}{*}{$22,60 \%$} & $\mathrm{OA}$ & $6,40 \%$ & $1,45 \%$ \\
\hline & & IMP & $15,30 \%$ & $3,46 \%$ \\
\hline & & INT & $19,80 \%$ & $4,47 \%$ \\
\hline & & DIR & $30,70 \%$ & $6,94 \%$ \\
\hline & & $\mathrm{TL}$ & $27,80 \%$ & $6,28 \%$ \\
\hline \multirow{5}{*}{$\begin{array}{l}\text { Functional } \\
\text { Competency }\end{array}$} & \multirow{5}{*}{$26,00 \%$} & INFO & $11,40 \%$ & $2,96 \%$ \\
\hline & & SCF & $8,70 \%$ & $2,26 \%$ \\
\hline & & EXP & $36,00 \%$ & $9,36 \%$ \\
\hline & & TW & $23,90 \%$ & $6,21 \%$ \\
\hline & & $\mathrm{CO}$ & $20,00 \%$ & $5,20 \%$ \\
\hline \multirow{2}{*}{ Working Condition } & \multirow{2}{*}{$5,00 \%$} & $\mathrm{CL}$ & $25,00 \%$ & $1,25 \%$ \\
\hline & & RA & $75,00 \%$ & $3,75 \%$ \\
\hline \multirow{2}{*}{$\begin{array}{l}\text { Technical } \\
\text { Competency }\end{array}$} & \multirow{2}{*}{$8,10 \%$} & Education & $50,00 \%$ & $4,05 \%$ \\
\hline & & Experience & $50,00 \%$ & $4,05 \%$ \\
\hline
\end{tabular}

Source: Expert Choice and Calculation

Step 5: Determine Point Values for each Compensable Factor

The maximum point value for salary calculation gained by multiplied total weight of each subfactors with 100.000. As the maximum value determined to be the highest level of each subfactors, the lowest level of each subfactors is obtained by dividing the maximum value with 10 . Scale is to be made to determine the interval value between each scale by subtracting maximum value with minimum value and to divide it by total scale minus 1 .

Step 6: Verify Factor Degrees and Point Values

Table 4 shows the determination of factor degrees and the point values for each compensable factor. 
Table 4 Factor Degrees and Point Values

Value of Core Competency

Scale

$\begin{array}{lrrrrrrrrrr}\text { Sub Factor } & 0 & 1 & 2 & 3 & 4 & 5 & 6 & 7 & 8 & 9 \\ \text { CSO } & 0 & 1003,5 & 2132,4 & 3261,2 & 4390,1 & 5519,0 & 6647,9 & 7776,8 & 8905,7 & 10034,6 \\ \text { FLX } & 0 & 356,2 & 997,3 & 1638,5 & 2279,6 & 2920,8 & 3561,9 & & & \\ \text { AT } & 0 & 563,0 & 1576,4 & 2589,8 & 3603,3 & 4616,7 & 5630,1 & & & \\ \text { DEV } & 0 & 766,0 & 1627,8 & 2489,5 & 3351,3 & 4213,0 & 5074,8 & 5936,5 & 6798,3 & 7660,0 \\ \text { ACH A } & 0 & 547,7 & 1251,9 & 1956,0 & 2660,2 & 3364,4 & 4068,6 & 4772,7 & 5476,9 & \\ \text { ACH C } & 0 & 593,7 & 2374,6 & 4155,6 & 5936,5 & & & & & \end{array}$

\section{Value of Managerial Competency}

\begin{tabular}{lrrrrrrrrrr} 
& \multicolumn{10}{c}{ Scale } \\
Sub Factor & 0 & 1 & 2 & 3 & 4 & 5 & 6 & 7 & 8 & 9 \\
OA & 0 & 144,6 & 405,0 & 665,3 & 925,7 & 1186,0 & 1446,4 & & & \\
IMP & 0 & 345,8 & 790,4 & 1234,9 & 1679,5 & 2124,1 & 2568,7 & 3013,2 & 3457,8 & \\
INT & 0 & 447,5 & 950,9 & 1454,3 & 1957,7 & 2461,1 & 2964,6 & 3468,0 & 3971,4 & 4474,8 \\
DIR & 0 & 693,8 & 1474,4 & 2254,9 & 3035,5 & 3816,0 & 4596,6 & 5377,1 & 6157,7 & 6938,2 \\
TL & 0 & 628,3 & 1570,7 & 2513,1 & 3455,5 & 4398,0 & 5340,4 & 6282,8 & &
\end{tabular}

\section{Value of Functional Competency}

\begin{tabular}{|c|c|c|c|c|c|c|c|c|c|c|}
\hline \multicolumn{11}{|c|}{ Scale } \\
\hline Sub Factor & 0 & 1 & 2 & 3 & 4 & 5 & 6 & 7 & 8 & 9 \\
\hline INFO & 0 & 296,4 & 741,0 & 1185,6 & 1630,2 & 2074,8 & 2519,4 & 2964,0 & & \\
\hline $\mathrm{SCF}$ & 0 & 226,2 & 735,2 & 1244,1 & 1753,1 & 2262,0 & & & & \\
\hline EXP & 0 & 936,0 & 2139,4 & 3342,9 & 4546,3 & 5749,7 & 6953,1 & 8156,6 & 9360,0 & \\
\hline TW & 0 & 621,4 & 1553,5 & 2485,6 & 3417,7 & 4349,8 & 5281,9 & 6214,0 & & \\
\hline $\mathrm{CO}$ & 0 & 520,0 & 1300,0 & 2080,0 & 2860,0 & 3640,0 & 4420,0 & 5200,0 & & \\
\hline
\end{tabular}

\section{Value of Working Condition}

\begin{tabular}{lrrrrrrrrrr} 
& \multicolumn{1}{c}{ Scale } \\
Sub Factor & 0 & 1 & 2 & 3 & 4 & 5 & 6 & 7 & 8 & 9 \\
CL & 0 & 125 & 500 & 875 & 1250 & & & & & \\
RA & 0 & 375 & 2062,5 & 3750 & & & & &
\end{tabular}

Value of Technical Competency

\begin{tabular}{lrrrrrrrrrr} 
& \multicolumn{1}{c}{ Scale } & & & & \\
Sub Factor & 0 & 1 & 2 & 3 & 4 & 5 & 6 & 7 & 8 & \\
Education & 0 & 405 & 2227,5 & 4050 & & & & & & \\
Experience & 0 & 405 & 2227,5 & 4050 & & & & &
\end{tabular}

Step 7: Evaluate All Jobs

Source: excel data processing

Those value then associated to each benchmark job's competency spesification that has been determined before. All points are totaled for each job, and all jobs are ranked according to their point values.

\section{Job Worth and Base Salary}

To gain an externallly competitive compensation system, survey for benchmark salary is needed. From several salary data, choosen Ganesha Operation's salary as the benchmark salary used. Ganesha Operation is the 
leader in tutoring industry as they could gained top brand award five years in a row. Assumed that GO salary is the most competitive salary that acceptable to their employee and lead to employees productivity and the corporate performance. So, in order to make the proposed competitive pay structure and boost company's competitive advantage the GO salary was chosen as benchmark salary.

The benchmark salaries then devided with each position's job value and used as the reference point or converter to calculate job salary of each position. Before calculating the salary of the jobs, the appropriate Pay Policy have to be considered. To make a solutive and strategic compensation system due to the business issue, considered that Lead Pay Policy is the suitable pay policy. With the policy of paying above-market rates it could maximizes the ability to attract and retain quality employees and minimizes employee dissatisfaction with pay.

So that, decided to use the highest converter value as the basis for calculate job salary. The chosen converter value is 113 , then it is multiplied with every job value, resulting each job's worth salary. Table 5 shows the calculation result of worth job salary.

Table 5 Job Salary

\begin{tabular}{|lcccc|}
\hline \multicolumn{1}{|c}{ Position } & $\begin{array}{c}\text { Salary } \\
\text { Benchmark }\end{array}$ & $\begin{array}{c}\text { Job } \\
\text { Value }\end{array}$ & $\begin{array}{c}\text { Benchmark/Job } \\
\text { Value }\end{array}$ & Job Salary \\
\hline General & Rp10.000.000 & 88397,1 & 113 & Rp10.000.000 \\
Manager & Rp6.000.000 & 68289,9 & 88 & Rp7.725.362 \\
Senior Manager & Rp7.331.933 \\
Branch Manager & Rp4.610.000 & 64812,1 & 71 & Rp \\
Supervisor & Rp4.140.000 & 56079,0 & 74 & Rp6.343.983 \\
Academic Staff & Rp2.300.000 & 31657,6 & 73 & Rp3.581.291 \\
Educator & Rp2.830.000 & 34649,1 & 82 & Rp3.919.715 \\
HR Staff & Rp2.000.000 & 30568,8 & 65 & Rp3.458.122 \\
Customer & Rp2.360.000 & 28014,0 & 84 & Rp3.169.112 \\
Service & Rp1.200.000 & 13999,3 & 86 & Rp1.583.685 \\
Operational & Rp1.710.000 & 15357,7 & 111 & Rp1.737.354 \\
Freelance Tutor & & & &
\end{tabular}

Those salary then compared with benchmark salaries' trendline, processed with linear regression using Microsoft Excel, resulted that those salary policy line was above the market pay line as seen in Figure 6 


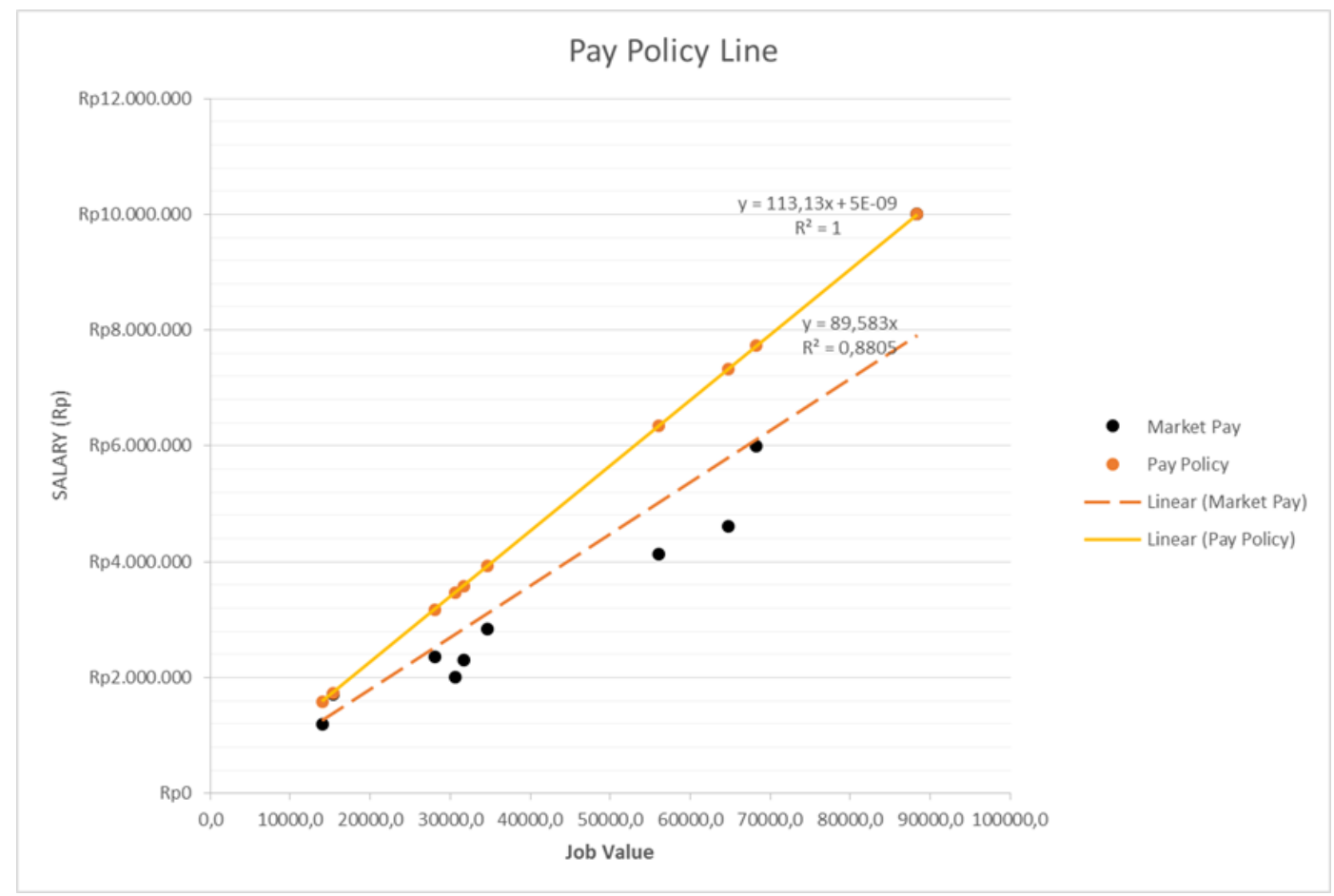

Figure 6 Pay Policy Line

Nevertheless, the application of salary calculation results to the company should have to pay attention to company's budget capability. Therefore, the scenario of pay was made thus Kursus Indonesia could adjust their pay decision with their financial condition. Table 6 shows some scenario of pay proposed with some percentage of pay compared to the worth salary and the budget needed to implement the pay scenario salaries.

\begin{tabular}{lccc}
\multicolumn{1}{c}{ Position } & \multicolumn{1}{c}{ Table 6 Proposed Scenario of Pay } & \\
General Manager & Rp10.000.000 & Rp9.500.000 & Rp9.000.000 \\
Senior Manager & Rp7.725.362 & Rp7.339.094 & Rp6.952.826 \\
Branch Manager & Rp7.331.933 & Rp6.965.336 & Rp6.598.740 \\
Supervisor & Rp6.343.983 & Rp6.026.784 & Rp5.709.585 \\
Academic Staff & Rp3.581.291 & Rp3.402.227 & Rp3.223.162 \\
Educator & Rp3.919.715 & Rp3.723.729 & Rp3.527.743 \\
HR Staff & Rp3.458.122 & Rp3.285.216 & Rp3.112.310 \\
Customer Service & Rp3.169.112 & Rp3.010.656 & Rp2.852.201 \\
Operational & Rp1.583.685 & Rp1.504.501 & Rp1.425.317 \\
Freelance Tutor & Rp1.737.354 & Rp1.650.487 & Rp1.563.619 \\
& Rp1.118.415.14 & Rp1.062.494.38 & Rp1.006.573.62 \\
Budget Needed & $\mathbf{2}$ & $\mathbf{5}$ & $\mathbf{8}$
\end{tabular}

In addition, due to some limitations to make job evaluation of all position in company, the pay grades was made by discussion with Kursus Indonesia's GM HC. Determined eight grades of jobs in accordance to Kursus Indonesia's career level. The pay range was made by executive consideration adjusted with company's carrer path and promotion policy. As shown in Figure 7 the pay range between every jobs stated from the minimum range to maximum range above and below the midpoint of pay policy line. This simulation will help the 
company or compensation officer to determine salary point for employee promotion.

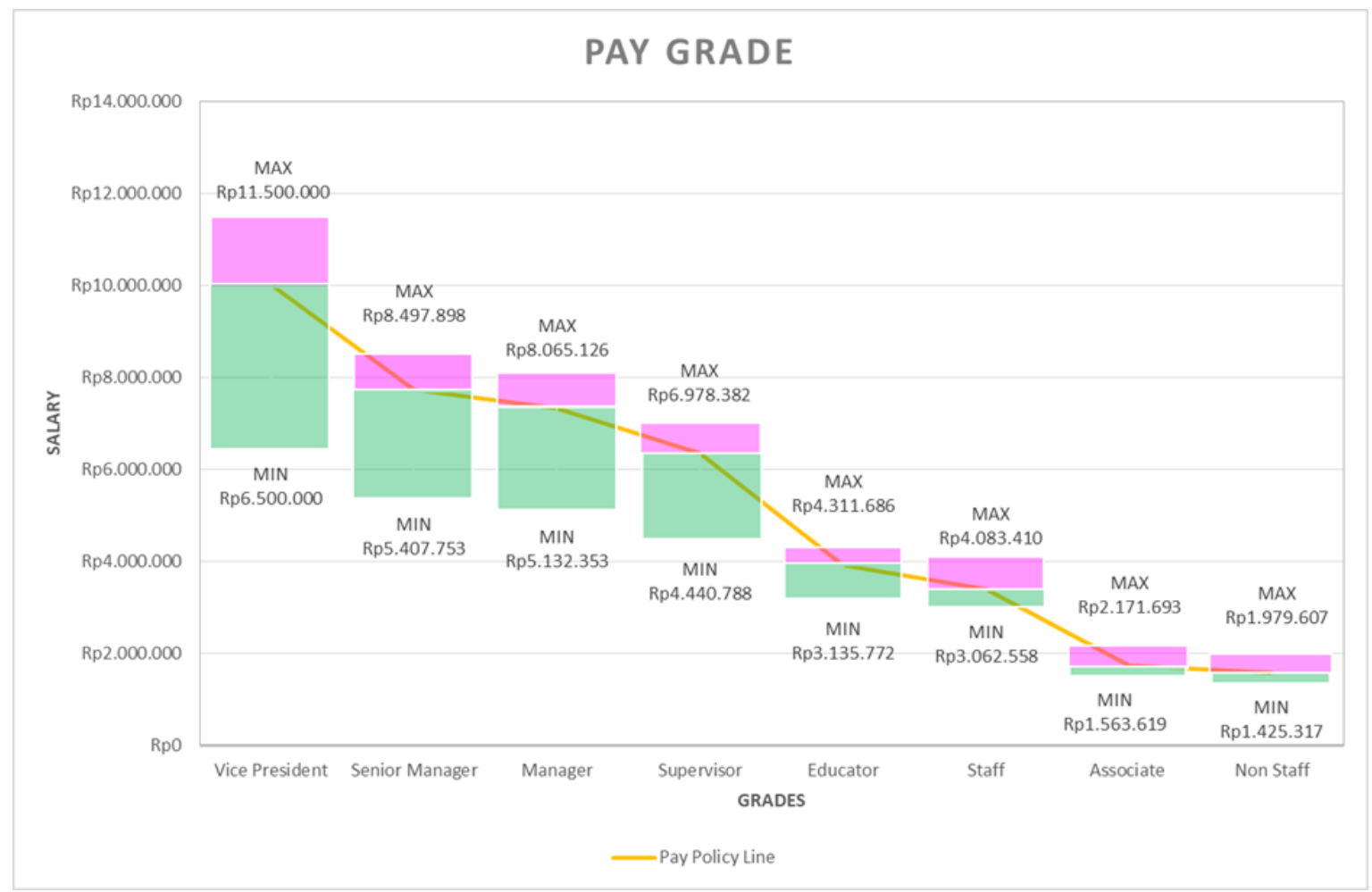

Figure 7 Pay Grade

There is still salary that below the Regional Minimum Wage for Non Staff and Associate. This grades acceptable with payment below the regional minimum wage because this positions considered as non staff in the company with no career ladder.

\section{CONCLUSIONS}

Based on the objectives of this study and the analysis, there are some outcome of this research that could be concluded:

1. From the root cause analysis, founded that the unalignment between compensation strategy and business strategy is the root cause of current Kursus Indonesia's compensation problem. This is made the current compensation system failed to bring internally fair and externally competitive compensation to the employees.

2. The proposed solution to solve Kursus Indonesia's compensation problem is by designing a Competency Based Pay system. This is the most appropriate approach because this system is suits to service industry to increase employee motivation and boost competitive advantage by generate competencies that support employee's needed behavior to support focus differentiation business strategy.

3. The salary recommendation result based on competency based pay system compared to the benchmark salary is more competitive, because it used a Lead Pay Policy that could maximizes the ability to attract and retain quality employees and minimizes employee dissatisfaction with pay as seen in Table 7. 
Table 7 Proposed Worth Salary Compared with Benchmark Salary

\begin{tabular}{|lcc|}
\hline \multicolumn{1}{|c}{ Position } & $\begin{array}{c}\text { Salary } \\
\text { Benchmark }\end{array}$ & $\begin{array}{c}\text { Proposed Job } \\
\text { Salary }\end{array}$ \\
General Manager & Rp10.000.000 & Rp10.000.000 \\
Senior Manager & Rp6.000.000 & Rp7.725.362 \\
Branch Manager & Rp4.610.000 & Rp7.331.933 \\
Supervisor & Rp4.140.000 & Rp6.343.983 \\
Academic Staff & Rp2.300.000 & Rp3.581.291 \\
Educator & Rp2.830.000 & Rp3.919.715 \\
HR Staff & Rp2.000.000 & Rp3.458.122 \\
Customer Service & Rp2.360.000 & Rp3.169.112 \\
Operational & Rp1.200.000 & Rp1.583.685 \\
Freelance Tutor & Rp 1.710 .000 & Rp1.737.354 \\
\hline
\end{tabular}

To implement the new compensation system, company should have a salary budget about 1 billion Rupiah. The implementation of the new compensation system could be executed by Kursus Indonesia's General Manager of Human Capital working together with human capital directorate's team by review the system, determine salary policies, obtain top's approval, communicate, execute, and monitor the new system.

\section{References}

Baron, A. (2007). Human Capital Management: Achieving Added Value Through People. Kogan Page Publishers.

Berger, L. A., \& Berger, D. R. (2000). The Compensation Hand Book. USA: McGrow-Hill Companies, Inc.

Denni, A. (2011). Desain Sistem Kompensasi Human Capital Berbasis Person Value Pada Perusahaan Agroindustri. Institut Pertanian Bogor.

Denzin, N. K., \& Lincoln, Y. S. (2000). Handbook of Qualitative Research (2nd ed). London: Sage.

Dettmer, H. W. (2007). The Logical Thinking Process: A Systems Approach to Complex Problem Solving. ASQ Quality Press.

Hitt, M. A., Ireland, R. D., \& Hoskisson, R. E. (2002). Strategic Management: Competitiveness and Globalization. South-Western: Thomson.

Jogiyanto. (2005). Sistem Informasi Strategik untuk Keunggulan Kompetitif. Yogyakarta: Andi Offset.

Martocchio, J. J. (2013). Strategic Compensation: A Human Resource Management Approach (7th Edition). USA: Pearson Education.

Maxmanroe.com. (2017). Viewed 16 November, 2017 at https://www.maxmanroe.com/situs-lowongan-kerja.html.

Milkovich, G, Newman, J., \& Gerhart, B. (2011). Compensation (10th Edition). New York: McGraw-Hill Education. 
Milkovich, G., Newman, J., \& Gerhart, B. (2014). Compensation (11th Edition). New York: McGraw-Hill Education.

Moeljono, D. (2003). Budaya Korporat dan Keunggulan Korporasi. Jakarta: PT Elex Media Komputindo.

Naukrihub. (2015). Payroll Management. Viewed 08 October, 2017 at http://www.naukrihub.com/payroll/

Porter, M. E. (1998). Competitive Strategy: Techniques for Analyzing Industries and Competitors. New York: Academy of Management.

Said, Z. (2017). Proposed Strategy Formulation and Implementation For PT Kursus Indonesia. Bandung: School of Business Management ITB.

Singh. (2007). Compensation and Reward Management. India: Excel Books India.

Spencer., \& Spencer. (1993). Competence at Work: Models for Superior Performance. Canada: John Wiley \& Sons, Inc.

Ulrich, D., \& Smallwood, N. (2004). Capitalizing on Capabilities. Harvard Business Review. 